\title{
Animais, alimentação e classe social
}

Juliana ABONIZIO*

RESUMO: Humanidade e animalidade são conceitos construídos de forma a criar uma determinada compreensão do que é ser humano. Apesar de o homem ser um animal é contudo, o único animal que cozinha e não o faz apenas para sua espécie. Os humanos se alimentam de animais e alimentam outros animais, sejam os de criação, engorda e venda, sejam aqueles eleitos para estima. Neste trabalho, proponho uma reflexão a partir da alimentação e forma corporal, sendo esses fatores determinantes, embora sujeitos à mobilidade social, da posição ocupada pelos animais humanos e não humanos na estrutura de classe.

PALAVRAS-CHAVE: Relações humano-animal. Alimentação. Estratificação social.

\section{Introdução}

Como parte do projeto Cidade multiespécie: as relações urbanas entre animais humanos e não humanos realizado na Universidade Federal de Mato Grosso, este artigo tem por objetivo refletir sobre as relações entre animais humanos e animais não humanos escolhidos para estima e companhia. Apesar de várias espécies poderem gozar da afeição e da convivência humana, incluindo aquelas consideradas exóticas, como cobras e iguanas, o cão ainda tem o título de melhor amigo do homem, sendo essa espécie a que mais convive com humanos nos lares brasileiros; por essa razão, foi a escolhida para esta análise.

Não obstante o apreço pelos cães, o amor não é ilimitado; assim, também há os casos de abandono e maus-tratos, mesmo entre aqueles considerados, ao menos verbalmente, inseridos na família. Animais velhos e doentes podem ser eutanasiados,

\footnotetext{
* UFMT - Universidade Federal de Mato Grosso. Programa de Pós-Graduação em Estudos de Cultura Contemporânea (ECCO-UFMT). Cuiabá - MT - Brasil. 78060-900 - abonizio.juliana@gmail.com https://orcid.org/0000-0002-8361-7262.
} 
mesmo que ainda possam ter uma sobrevida sem sofrimento, se forem requeridos tratamentos custosos de tempo e dinheiro. $\mathrm{O}$ abandono e o sacrifício não são raros, como demonstra Segata (2016) ao discutir a respeito da cadela Belinha, que, abandonada pelos donos após dez anos de convivência, sobreviveu nos fundos de uma clínica veterinária como estoque de sangue para doação.

A causa de sua velhice pouco saudável, segundo o autor, seria explicada, possivelmente, por uma alimentação mal balanceada no passado, já que era bastante corriqueiro que a dieta dos animais fossem as sobras da comida dos humanos. O que ainda ocorre, especialmente em lares mais pobres.

Segundo o estudo clássico de Kulick (2009), James Spratt, ao ver cães revirando lixo em Londres, teve a ideia de produzir biscoitos caninos de carne por volta de 1860 e, passada uma década, passou a vender os tais petiscos nos Estados Unidos, conquistando um grande público consumidor e se espalhando por vários países. Segundo o autor, através de uma publicidade intensa, criou-se uma necessidade até então inédita: comprar comidas feitas exclusivamente para os animais de companhia. No aprofundamento da sua reflexão, Kulick (2009) demonstra que no mercado de rações, o que mais cresce e também é o mais dispendioso é o segmento das rações especializadas.

Tal reflexão acerca da nutrição adequada aos animais traz como anexo o debate sobre a nutrição humana, afinal nem todos os humanos têm o direito efetivo a uma alimentação adequada e, portanto, nem todos os humanos têm o direito de fornecer uma alimentação adequada ao animal de sua estima. A alimentação, desse modo e pelo seu preço, cria critérios de diferenciação social baseada no poder de consumo: a) sobre quem tem ou não direito a tutelar animais; $b$ ) sobre os animais que têm ou não acesso a uma alimentação diferenciada. Nesse caso, a diferenciação que atinge animais humanos e não humanos é baseada no consumo alimentar, não importando se se trata de quem come ou de quem paga pela comida.

No entanto, Kulick (2009) não aborda apenas a questão da alimentação dos pets, aborda também o corpo que portam. Em resumo, os "gordotes", como cita o autor, já foram considerados fofos e engraçados, mas, na atualidade, os cães magros gozam de maior prestígio na escala social, ao lado de seus donos também magros.

Desse modo, podemos aferir que a forma corporal e a alimentação, à exceção de casos relativos à medicina, estão interligadas e identificam pertencimentos a determinados extratos sociais. Os corpos gordos associados à comida processada e de má qualidade são localizados nos extratos inferiores. Ao contrário, pertencem às camadas mais ricas da sociedade os corpos magros, de humanos e animais, associados 
às dietas balanceadas, sejam de rações específicas, sejam de comidas light e diet ou ainda de orgânicos, todas evidentemente mais custosas.

Segundo o já citado Kulick (2009), a obesidade tem diminuído a fronteira entre a espécie humana e as demais espécies, contudo, sem discordar do autor, pretendo retomar a discussão entre as (in)definições entre humanidade e animalidade. Pelo menos até o momento, apesar de alguns experimentos questionarem o que afirmo a seguir, o homem é o único animal que cozinha e a comida tem sido bastante relevante na aproximação interespecífica de três modos: a aproximação com espécies silvestres mediante oferta de comida como atrativo para o contato; a atribuição de humanidade aos animais de companhia, que já têm livros de receitas e padarias próprias ao seu consumo; a privação da humanidade aos humanos pobres e/ou gordos.

Diante do objetivo proposto de refletir sobre as relações entre animais humanos e animais não humanos escolhidos para estima e companhia, utilizei referenciais teóricos dos estudos humano-animal, da sociologia e antropologia da alimentação e estudos sobre corporalidade.

\section{A construção do humano}

A comparação entre humanos e animais é uma constante nas sociedades e é a própria comparação que cria a distinção que torna as espécies passíveis de serem comparadas. Dito de outro modo, a linha entre os humanos e os demais animais foi construída a partir da comparação. Devemos acrescentar que quem fez a comparação foram justamente os humanos, então a tal linha construída não separa as espécies em sua horizontalidade, mas verticaliza a relação e a bibliografia mostra que a supremacia da espécie humana foi referendada pela constatação daquilo que falta às demais espécies, ainda que essa falta seja retórica, inventada ou comprovada. Do mesmo modo, a supremacia do branco europeu foi construída a partir do que falta em outras culturas e etnias, como grafia e Estado, dentre outros traços culturais (CLASTRES, 1978). Cabe ainda ressaltar que nem todos os seres que hoje são considerados humanos assim o foram desde sempre, alguns tendo sido tratados como animais, monstros ou subumanos. As categorias e os critérios mudam ao longo do tempo, mas a distinção permanece.

Se a convivência interespecífica e a convivência intercultural são evidentes e constantes, seja mediante o processo de colonização ou mesmo lhe sendo antecedente, pois a pureza e isolamento são frequentemente ideais, as maneiras de se relacionar com as espécies são diferentes, ou pelas características da própria espécie, o que inclui sua capacidade agenciadora, ou por atribuições de significados a essas espécies, como nos 
mostram Arluke e Sanders (1996) ao discutirem a existência de uma escala sociozoológica na qual cada sociedade situa os animais, considerando determinadas espécies mais inteligentes, boas ou más, bonitas ou feias, comíveis ou incomíveis, mais ou menos carismáticas, dentre outras variáveis.

De modo similar, os monstros servem epistemicamente para a definição daquilo que cabe na categoria humano. Para José Gil (1994), os monstros, por definição excessivos e situados em fronteira, não são completamente opostos aos humanos, mas seres híbridos que não se conformam plenamente à humanidade. Enfim, é pelo outro que nós sabemos de nós, sendo esse outro bicho, gente ou coisa.

Segundo Tim Ingold (1995),

a melhor maneira de demonstrar essa diferença é examinar a maneira pela qual as noções de humanidade e de ser humano determinaram, e foram, por sua vez, determinadas, pelas ideias acerca dos animais. Para nós, que fomos criados no contexto da tradição do pensamento ocidental, os conceitos de "humano" e "animal" parecem cheios de associações, repletos de ambiguidades e sobrecarregados de preconceitos intelectuais e emocionais. Dos clássicos até os dias de hoje, os animais têm ocupado uma posição central na construção ocidental do conceito de "homem" - e, diríamos também, da imagem que o homem ocidental faz da mulher. Cada geração reconstrói sua concepção própria de animalidade como uma deficiência de tudo o que apenas nós, os humanos, supostamente temos, inclusive a linguagem, a razão, o intelecto e a consciência moral. E a cada geração somos lembrados, como se fosse uma grande descoberta, de que os seres humanos também são animais e que a comparação com os outros animais nos proporciona uma compreensão melhor de nós mesmos. (TINGOLD, 1995, n.p.).

Através de uma instigante discussão sobre a caracterização das espécies, sendo que todas, animais e vegetais, têm larga escala de variação interna, e retomando o homem com cauda discutido por Lineu a partir de uma descoberta de Momondo de uma ilha cujos moradores seriam humanos fenotipicamente à exceção de possuírem cauda, o que tornava questionável sua estada no podium da humanidade, foi levantada a questão: se há homens de várias estaturas, cores e outras variações, por que não haveria homens com ou sem cauda? Para Ingold (1995), existe um feixe de possibilidades dentro de cada espécie viva, cuja complexidade pode ser atestada pela variabilidade, mas também pela semelhança, do DNA. Contudo, nem mesmo o DNA nos dá certeza de nosso pertencimento étnico, tampouco da exclusividade da nossa humanidade. A ciência, ao que parece, mesmo sendo um construto epistemológico branco-europeu que se autoproclama como a forma de conhecimento mais evoluída e válida universalmente, 
como apregoava o positivismo, não tem tido sucesso comprobatório na cisão entre humanos e animais e na justificativa da dominação dos últimos pelos primeiros. Aquilo que é certeza para determinadas culturas, para o senso comum ou diversas religiões, passa a não ter o aval fornecido pela ciência.

Para Ingold (1995), os filósofos buscam a essência da humanidade na cabeça dos homens e, em vez de procurar compreender a espécie humana, buscam diferenciála das outras milhões existentes, separando tal espécie do reino animal através dessa retórica. Disso resulta que a busca da essência humana está naquilo que as outras espécies não têm, embora cada vez mais se descubra que os critérios de ausência e presença são fictícios. Assim, aos animais era negada a presença de alma - apesar de haver ao menos um cachorro santo na história segundo meu conhecimento, o caso do cachorro santo Guinefort, alvo de adoração na Europa medieval (BAPTISTELLA; ABONIZIO, 2016). Além da alma, também já foram negadas pela ciência a presença de dor e sofrimento; a consciência da morte; a vocalização, consciência de identidade ou individualidade, negações que passaram a ser questionadas pela própria ciência, que só atentou para isso a partir da crise ecológica, da pressão dos movimentos sociais e das descobertas principalmente da etologia cognitiva.

No estudo de Ingold (1995), e em outros que seguem a mesma linha, não apenas a distinção de natureza entre animalidade e humanidade é questionada, mas a universalidade da ciência positivista utilizada como justificativa epistemológica para dominação entre espécies e entre etnias é posta em xeque. A diferença que era motivo de apartação e dominação parece já não gozar do mesmo prestígio e isso ocorre, inclusive, dentro da própria ciência (BAPTISTELLA; ABONIZIO, 2016).

Os humanos, autodeclarados, também criaram critérios hierárquicos dentro de sua própria espécie que poderiam incluir ou excluir outros humanos desse tipo de clube exclusivo. Assim, algumas etnias eram desumanizadas, o que justificaria a escravidão negra e indígena e também a perseguição aos judeus. Também se separavam os humanos racionais e civilizados dos selvagens ou bárbaros, especialmente pelo fato de pertencer ou não a uma cultura grafológica ou possuírem alma. Os seres em questão entravam e saíam da condição de humano, dada exteriormente pelos homens de ciência; mesmo quando considerados humanos, seriam de um tipo inferior da espécie. Assim se baseia a história de uma humanidade única, sonhada pelos positivistas e realizada com todo o tipo de violência, física, psicológica e epistemológica, a partir da dominação colonial cujas feridas ainda estão longe de serem cicatrizadas.

Retomo a importância de Aristóteles dada a recorrência da utilização de seus argumentos na história ocidental, ainda que sem desejo ou necessidade de recontá-la. Para o filósofo, a alma se separa em três tipos, a nutritiva, a sensível e a racional, sendo 
esta exclusiva aos homens. Em sua concepção, o homem não é apenas um animal superior, mas pertence a outra natureza, de acordo com Rambo e Renk (2008). Segundo os autores, a transição do mito ao logos ocorre até o ponto de o homem se assumir como pensante e autônomo em relação à natureza. Do mesmo modo, no cristianismo, o homem transcende a natureza sem nela se situar, sendo concebido como um ser privilegiado.

Nessa visão teocêntrica, segundo os autores, seria melhor para as vacas e ovelhas estarem sob o domínio do homem em vez de estarem na natureza inóspita; além do mais, "os sofrimentos dos seres brutos não eram como os do homem. Eles não tinham nenhuma concepção de futuro e nada perdiam por serem privados da vida. A autoridade humana era assim virtualmente ilimitada" (RAMBO; RENK, 2008, p. 69).

Já no Iluminismo, fazendo um salto histórico apenas para exemplificar como na longa tradição ocidental a separação entre natureza e cultura e animalidade e humanidade foram concebidas, os autores retomam Descartes, para quem o método, coroado com o título de científico, possibilitava, através da divisão sistemática, provar hipóteses; assim, sua primeira cisão foi entre corpo e mente, e a partir de 1630 vê os animais como autômatos incapazes de raciocinar ou sentir. Isso também ocorria com o corpo humano, pensado como uma máquina, sendo sua singularidade apenas o fato de possuir uma mente, o que falta aos animais, considerados apenas corpos.

Desse modo, retomo, a humanidade seria caracterizada por tudo aquilo que é ausente, ou se crê ausente, nas demais espécies, como linguagem simbólica, cultura, tabu do incesto, trabalho, consciência, ou senciência, designação que tem apresentado maior uso dentre estudos acadêmicos e discursos protecionistas e abolicionistas. Embora não haja consenso, as três dimensões consideradas de consciência, cognição, autoconsciência e senciência têm sido pesquisadas inclusive em animais invertebrados, como o estudo de Magalhães-Sant'Ana (2009).

O senso comum compra essa ideia ao seu próprio modo e vê na animalidade a presença do amor incondicional e na humanidade a presença de inveja, maldade, ganância (BAPTISTELLA; ABONIZIO, 2015), cujos opostos seriam ironicamente valores considerados humanos noutro sentido possível do termo, mais ligado ao humanismo e ao humanitário do que à condição de bicho ou gente.

Ressalto que essas características gozaram de boa consideração em meios acadêmicos e não acadêmicos e ainda gozam nalguns deles, mas esse paradigma também é questionado com as descobertas da etnologia cognitiva e relativizado pelos estudos humano-animal, corrente de pesquisa interdisciplinar que vem crescendo nas últimas décadas. 
Assim, para provar que animais sentem dor, Chuahy (2009) cita um teste de laboratório realizado pela Escola de Ciências Biológicas da Universidade de Liverpool, que comprova que, diante da provocação de uma queimadura em alguma parte do corpo, o animal afasta essa parte, evitando o sofrimento, conclui-se (BAPTISTELLA; ABONIZIO, 2016).

Com essas descobertas, valores antes considerados estritamente humanos, como moral, passam a ter existência comprovada em outras espécies, como o caso já clássico dos macacos que reivindicam justiça numa querela por uvas e pepinos.

Em uma palestra apresentada em 2011, o primatologista e etologista Franz De Waal conta como começou a estudar a agressividade nos primatas e então descobriu que eles se reconciliavam. $\mathrm{Na}$ época, não parecia fazer sentido que ganhador e perdedor buscassem restabelecer

o relacionamento, inclusive com troca de carinhos. O que ele fez nos anos seguintes foi observar e realizar testes para comprovar a cooperação entre os animais. Os experimentos conseguiram demonstrar que os chipanzés retribuíam favores. Cientificamente, De Waal (2011) estava comprovando a reciprocidade e a empatia nos animais, dois comportamentos apontados por ele como os pilares da moralidade. Para ele, os bichos também teriam senso de justiça. Pesquisadores ofereceram pepinos a dois macacos como pagamento pela realização de uma tarefa simples. Tudo certo até que um deles começava a ser pago com uvas. Aquele que recebia o pepino claramente se revoltava: batia no acrílico da sua gaiola e esticava o braço, batendo na mesa de testes. (BAPTISTELLA; ABONIZIO, 2016, p.93).

Franz de Waal (2011) concluiu que havia presença de comportamento moral em animais. Apesar de não equiparar a moralidade humana à animal, já não se podia negar a existência de senso de justiça, empatia, dentre outros atributos que se criam exclusivamente humanos e, mais, que permitiam a separação entre humanos e todas as outras espécies existentes e extintas.

Ressalto que os animais em questão não eram voluntários de uma pesquisa, mas cobaias à revelia e em uma necessária (segundo a ciência, criação humana, baseada em comprovações) experiência que trouxesse a certeza de um mundo subjetivo que até então se cria restrito aos humanos, o que só foi possível através das descobertas científicas, pois estas gozam na modernidade de grande credibilidade (BAPTISTELLA; ABONIZIO, 2016).

Para Maffesoli (1999), a modernidade, com suas promessas de progresso, causou um desencantamento do mundo, cada vez mais burocratizado e racionalizado. Contudo, no que o autor chama de pós-modernidade, diante da decepção das promessas 
não cumpridas em nome de um desenvolvimento, vivemos em um processo de reencantamento do mundo. Nessa nova época, em vez de um mundo desenvolvido, busca-se maior envolvimento, uma forma mais holística de perceber o mundo. Na pósmodernidade, ou no processo de pós-modernização, o conhecimento científico passa a ser questionado, uma vez que os estragos causados em seu nome, no que se chama natureza, humanidade e animalidade, o tornaram alvo de contestação.

No entanto, a ciência ainda goza de prestígio. No exemplo citado, a dor animal teve de ser comprovada em um experimento, apesar de qualquer tutor ter a mais pura certeza de sua existência quando percebe que seu animal está sofrendo. Por outro lado, a moralidade humana não carece de comprovação, mas o comportamento imoral, sim, como demonstram os estudos de Milgram, nos quais a obediência a uma autoridade parece suspender a capacidade de julgamento moral e consequência das ações (RING; WALLSTON; COREY, 1970). Em suma, a amoralidade animal e a moralidade humana são crenças apriorísticas e seus opostos não são assim tão evidentes e necessitam de corroborações científicas.

Diante das (in)definições sobre o que delimita ou deixa de delimitar a humanidade e a animalidade, assistimos ao crescente movimento pelos direitos dos animais, alçando outras espécies à entrada definitiva na comunidade moral da sociedade da qual participam, mas sem grande consideração em papéis diversos, seja como trabalhador, instrumento de carga, companhia, matéria-prima, etc. Mas cabe ainda a ressalva de que essa pluralidade de papéis sociais atribuídos aos animais ocorre majoritariamente, ou mesmo exclusivamente, quando se trata de vertebrados (NACONECY, 2007), apesar do que revelam os estudos já citados do médico veterinário, mestre em bioética, Magalhães-Sant'Ana (2009).

Faço questão de dizer que animais sempre participaram da vida social, assim como as coisas têm vida social (APPADURAI, 2008), não sendo, pois, o estudo das relações sociais - grosso modo o objeto da sociologia - restrito às relações interhumanas.

Nos últimos anos, a emergência da categoria pet aliada ao crescimento dos direitos animais complexifica a distinção que se cria natural ou mesmo evidente entre a humanidade e a animalidade na cultura ocidental. Desse modo, temos famílias interespecíficas, que assim se julgam, apesar do tipo de parentesco ter nuances próprias, o que torna necessário relativizar o título de filho e irmão ao lugar ocupado pelos humanos que recebem a mesma designação. Ainda é importante destacar que já há mais animais que crianças nas famílias. 
[...] de cada 100 famílias no país, 44 criam cachorros, enquanto só 36 têm crianças. [...] o resultado do cruzamento de dados saiu apenas na semana passada. Ele apontou a existência de 52 milhões de cães, contra 45 milhões de crianças até 14 anos - uma situação que se assemelha à de países como o Japão (16 milhões de crianças, 22 milhões de animais de estimação) e os Estados Unidos (em 48 milhões de lares há cães; em 38 milhões há crianças). (RITTO; ALVARENGA, 2015, p.71).

Os nomes e sobrenomes já não se distinguem e os hábitos de consumo comprovam a semelhança real ou imaginada por tutores. Atualmente, como estudou Kulick (2009), a maioria dos animais de companhia tem nomes humanos e divide a cama com os tutores. Mas é preciso destacar que há também uma diferenciação entre classes sociais que é estendida aos animais, e não falo tão somente das raças ou ausência de raças, mas da consideração em relação aos animais e ao que se compreende por animalidade. Dessa forma, ressalto o conhecimento do homem comum, destacado por Berger e Luckmann (1999), que debatem como um certo tipo de conhecimento vem a ser considerado conhecimento em uma sociedade independentemente das balizas científicas. Os animais da periferia, mais comumente, podem ser vistos dando uma volta na rua, que também é ocupada por crianças e moradores em momento de ócio, o que não ocorre em bairros nobres. O quintal ainda é moradia por excelência de animais suburbanos, independentemente de exercerem ou não a função de guarda. Trato aqui de uma tendência, pois, em uma mesma casa, cães diferentes ocupam espaços diferentes. Em geral, os de pequeno porte têm acesso aos cômodos interiores, sendo estes mais frequentemente interditados aos de grande porte ou sem raça definida, que, apesar de gozarem de estima, não entram na categoria de membros da família, ocupando um espaço indefinido entre o animal de companhia e o animal de guarda. Dito de forma direta: não são considerados membros da família, raramente dormem na cama e têm nomes que geralmente não são atribuídos a humanos.

Por meio do relacionamento diário, os bichos mostram aos tutores que têm personalidades definidas. No entanto, até pela necessidade de buscar uma aproximação conceitual, há um esforço em modular o comportamento dos pets, em uma tentativa mal disfarçada de lhes dar aspectos de humanidade, como se esta fosse uma característica necessariamente superior. É um traço especista do relacionamento que revela a permanência da crença de que o ser humano é superior a outras formas de vida, ainda que seja igualmente comum ouvir frases que advogam a supremacia do animal que não teria valores considerados negativos, como maldade, inveja ou interesse, além de manifestações do tipo: "Prefiro bicho 
a gente". Mas, obviamente, não são quaisquer seres contidos na categoria bicho, os referidos. (BAPTISTELLA; ABONIZIO, 2015, p.4).

Diante desse quadro de redefinições emocionais, jurídicas, comportamentais, científicas, etc. sobre o que distingue a humanidade da animalidade e sobre aquilo que as indissocia, escolhi a alimentação como elemento tanto de aproximação quanto de distanciamento entre as espécies e a sua localização na estratificação social.

\section{Você é o que você come?}

Todos os animais comem. Todos se alimentam. Há animais carnívoros, onívoros, herbívoros, canibais, carniceiros. Só uma espécie, contudo, cozinha, embora haja controvérsias recentes sobre essa exclusividade: "Um estudo da Universidade de Harvard acaba de revelar que mesmo nossos primos mais próximos, os chimpanzés, são perfeitamente capazes de entender, da roça ao prato, todas as fases da preparação de alimentos". (MARTON, 2016, n.p.).

Até o momento, pelo menos, o ato de cozinhar é mais do que se alimentar. É revestido de símbolos, sendo o consumo alimentar algo que ultrapassa em muito a obtenção de nutrientes, constituindo-se em uma forma de dar sentido ao mundo (DOUGLAS; ISHERWOOD, 2009) ou de contar histórias (AMON; MENASCHE, 2008). Nesse sentido, o ato de cozinhar é considerado estritamente humano e a espécie humana não cozinha apenas para si mesma.

A alimentação aparece como um importante vínculo interespecífico de vários modos em diferentes épocas e culturas. Somente como exemplo, o cuidado do pasto, a construção de cochos nas cidades para os cavalos imperiais, a lavagem dos porcos, os milhos para galinhas e pombas e suas controvérsias, a ação indesejada e quase automática de ofertar alimentos a animais silvestres na busca de uma intimidade, o que também acontece em zoológicos, costume atestado pela existência das placas proibitivas. Todas essas e outras práticas nos mostram como a alimentação serve como vínculo, seja desejado ou indesejado. Desse modo, alimentar animais de rua é visto como a criação de um vínculo indesejado, sendo frequentes reclamações em condomínios e instituições públicas acerca das pessoas que alimentam animais vadios que se acostumam ao local por receberem comida, como o caso já estudado acerca dos gatos do Tribunal de Justiça de Mato Grosso (BAPTISTELLA; ABONIZIO, 2015); em outro exemplo, há uma placa com o rosto de um filhote de gato na Universidade Federal 
do Rio Grande do Norte com a inscrição, mais explícita impossível: "Não alimente esse problema".

A alimentação de pequenos símios, com frutas, ou de aves benquistas (não falo de pombas que são consideradas como pragas no Brasil, mas atrativas nas praças de Bogotá, onde se vende milho justamente com o propósito de aproximação) é hábito visto como bom justamente porque tais espécies se acostumam ao local e enchem os olhos dos que por ali passam.

Com os humanos, acontece coisa parecida e também diferente. Nas casas em que mendigos pedem por comida, em bairros periféricos ou nos interiores do país, as donas de casa dizem, com variações, que não se pode dar sempre sobras de comida, pois, caso contrário, "o mendigo acostuma”. Na política atual, o discurso mais frequente é o que combate o direito à alimentação com a ideia da importância do ensinar a pescar, como se fosse a ignorância do pobre a causadora da fome, o que se contradiz com um projeto político que atua com descaso com a educação.

Cozinhar, como já disse, é um ato humano e um saber fazer variado que define o que vai ser comido ou descartado, a forma com que será servido e o quanto, a ordem de comer, o que se mistura ou não, as técnicas de cocção e apresentação, em que estão presentes diversas crenças nutricionais, às vezes em conflito, como vemos na cultura contemporânea. Ao que parece, a ideia de Fischler (1995) sobre o período atual como "gastro-anômico" não mudou muito desde a segunda metade do século XX, ou, melhor dizendo, mudou, mas a noção de "gastro-anomia" parece resistir, dada a variedade e incompatibilidade de dietas, seja low carb, cetogênica, orgânica, jejum intermitente ou demais variedades que abundam na imprensa, especializada ou não. É também nesse período que cresce a estigmatização de pessoas gordas, especialmente nas camadas mais altas, mas que atingem rapidamente todos os segmentos sociais, como comenta Fischler em entrevista a Goldenberg (2011). Há mudanças mesmo na cultura moderna ocidental. Se os pais eram os primeiros a serem servidos e as crianças, as últimas, a coisa se inverteu. Atualmente, é frequente a criança ter poder de decisão sobre a alimentação dos demais membros da família, sobretudo quando se trata do hábito de comer fora. Os animais, que já comeram os restos das mesas humanas, agora são servidos antes, até para não ficarem pedindo petiscos (e fugindo de sua prescrição dietética), e são bem aceitos em muitos restaurantes em que os donos dividem seu prato com os animais tutelados através da prática de atirar pequenos nacos como agrado, apesar de, em entrevistas, muitas vezes afirmarem ser a ração o único alimento ofertado, como já mostrado em trabalhos anteriores (ABONIZIO; BAPTISTELLA, 2017).

Diante do exposto, escolhi a culinária (e tudo o que a envolve, sendo uma atividade exclusivamente humana) para analisar a dicotomia entre a animalidade e a 
humanidade e como essas noções se aproximam e distanciam. Visando complexificar a análise, introduzi o viés de classe, pois, na estrutura social, humanos, coisas e também animais podem vincular-se a diferentes camadas que compõem a estratificação social vigente. Do mesmo modo que há ricos e pobres, há comidas de rico e comidas de pobre e animais tutelados por ricos e pobres, distinguindo-se em espécie e também em raça, mas sobretudo no tratamento que lhes é conferido. Assim, um cão vendido por um preço considerado caro pode habitar a mesma casa de um cão sem raça definida que tenha caído nas graças do tutor. Já espécies como cavalo e gado, sobretudo de competição, são exclusivas das mais abastadas camadas sociais, nem sequer sendo cogitadas como sonho de consumo de qualquer cidadão abaixo dessa linha. Ressalto que priorizei cães nessa reflexão entre classe social, desigualdade social, alimentação e relações entre humanos e animais.

\section{Corpo, comida e estratificação}

Para Rodrigues (1983), o corpo é marcado pela sociedade, sendo uma materialização da estrutura; desse modo, o que foge à regra traz o risco da desestruturação e assim ameaça a coesão social. Os padrões corporais se modificam com o tempo e, apesar de o corpo ser portado por um indivíduo, sua forma, tamanho, peso, etc. são definidos socialmente e ele está sujeito a coerção se fugir às regras, sendo o indivíduo responsável por sua adequação e manutenção dentro dos parâmetros estabelecidos, o que retira qualquer incumbência de políticas públicas.

Atualmente, há intensa discussão sobre obesidade, e não só do ponto de vista das ciências da saúde; mais recentemente, tal discussão adentra o campo das humanidades. Afinal, qual o lugar do corpo gordo na sociedade contemporânea?

Sem dúvida, o corpo gordo, além do próprio peso, carrega o peso do estigma, no sentido emprestado de Goffman (1975), e é indisfarçável, a não ser quando se trata de pequenas gordurinhas que podem ser esmagadas em cintas modeladoras a fim de ajustar a silhueta ao padrão de beleza do momento. No entanto, afirma Vigarello (2012):

O gordo, porém, nem sempre foi tão estigmatizado. O que já justifica uma investigação histórica. As anatomias maciças podiam ser apreciadas, por exemplo, na Idade Média, como sinal de poderio, ascendência. [...] Imagens complexas sem dúvida, pois são contestadas nessa mesma Idade Média pela pregação clerical, a reserva e a certeza médicas ou mesmo as exigências por vezes minuciosas da 
etiqueta cortesã; imagens no entanto marcantes, imediatamente identificáveis, que dão ao gordo poderio e convicção. (VIGARELLO, 2012, p.9-10).

Na Europa moderna, o gordo passa a ser a excorporação da preguiça, do descuido e da grosseria. Apesar das reviravoltas acerca dos sentidos da gordura, as sociedades ocidentais se desenvolvem afinando o corpo, vigiando e rejeitando o peso. Enquanto a beleza se aproxima do esguio, o volume se afasta do refinamento e, na modernidade, o corpo gordo é simultaneamente falta de delicadeza e falta de eficiência (VIGARELLO, 2012).

Em uma sociedade em que há um apressuramento (PAIS, 2010), o corpo gordo peca na falta de agilidade e também é criticado por descuido, falta de controle, tristeza, fracasso íntimo, revelando, num tipo de psicologização, pela forma ostentada, traços de apatia e tristeza (VIGARELLO, 2012).

Para Poulain (2013), a obesidade torna-se um problema de saúde pública quando as empresas de seguro dos EUA relacionam índice de gordura, expectativa de vida e despesas com saúde, sendo que os mais gordos têm maiores índices de morbidez, uma vez que a obesidade se relaciona a doenças cardiovasculares e diabetes tipo 2 . Desse modo, a obesidade era um fator de risco e "como tal deveria ser evitada e vigiada, mas ainda não era considerada como uma doença" (POULAIN, 2013, p.143). Só posteriormente é designada como doença mortal e epidêmica. No entanto, o autor questiona essa visão diante da controvérsia entre a ciência e a mídia, que traz ao debate também elementos e interesses sociais, políticos e econômicos.

Se, de um lado, a estimativa da Organização Mundial da Saúde (OMS) é de que haja mais de 700 milhões de pessoas obesas e 2,3 bilhões com sobrepeso até 2025, mas sem dizer claramente que se trata de uma doença, a American Medical Association declarou a obesidade como doença em 2013. No Brasil, a definição não é consensual, embora a Associação Brasileira para o Estudo da Obesidade e da Síndrome Metabólica (ABESO) a considere uma doença (OBESIDADE, SAIBA..., 2020)

Considerando a obesidade fator de risco ou doença, o peso é pago pelo gordo numa sociedade lipofóbica, que o responsabiliza pelo seu descuido, descontrole e por uma falha moral. Apesar de atingir a todas as classes, isso não se dá da mesma forma.

Kulick (2009) começa seu texto descrevendo dois casos de cães obesos que foram tirados de seus tutores por ter-se considerado que a obesidade era um caso de maus-tratos. Cada história tem um fim diferente no país em que ocorre, mas o que pretendo destacar é a visão negativa do cão gordo. Segundo o autor, trata-se de um fenômeno recente, pois animais de companhia que até então eram considerados fofinhos, hoje seriam considerados obesos e motivos de preocupação. 
Os motivos pelos quais a obesidade é ruim para os animais de estimação, de acordo com as companhias de alimentos direcionados a eles, é que estes animais, quando gordos, são mais vulneráveis a problemas no coração, doenças no fígado, problemas musculares e ósseos, diabetes e, segundo dizem alguns, alergias. Uma afirmação ubíqua é a de que a obesidade encurta o tempo de vida dos animais de estimação. A fonte desta assertiva é um estudo de 2002, feito pela companhia de alimentos para estes animais Nestlé Purina, que criou 48 labradores e deu à metade deles $25 \%$ menos comida do que à outra metade, desta forma mantendo-os abaixo de seu peso ideal. Os cães que receberam menos comida viveram em média 1,8 anos mais que o grupo de controle (Kealy, Lawler, Ballam et alli 2002). A forma como isto é invariavelmente reproduzido é através da afirmativa de que animais de estimação gordos morrem prematuramente. Até onde consegui descobrir, este é o único estudo que indica que os cães magros vivem mais do que os gordos. (KULICK, 2009, p.491).

Ao fim do texto, o autor diz que a obesidade tem aumentado, mas também a expectativa de vida, tanto humana quanto de seus companheiros animais. A despeito disso, há um crescimento dos produtos com pouca gordura, tanto para animais quanto para seus humanos.

Esse mercado é obviamente o mais caro, como comprova Kulick (2009) no caso dos animais e como comprovei em um estudo sobre mobilidade social ascendente e a mudança de hábitos alimentares em mulheres em Mato Grosso (ABONIZIO; JIMENEZ-JIMENEZ, 2018). A ascendência social das mulheres entrevistadas não mudava somente o acesso a alimentos mais caros ou considerados sofisticados, mas significava também a entrada no consumo light e diet, o que não ocorria pelo sabor, mas por ver na possibilidade de comprar produtos mais caros e menos calóricos a chance de emagrecimento e de dar visibilidade ao seu novo pertencimento social, ostentado nos carrinhos dos supermercados e, sobretudo, nos números cada vez menores das etiquetas sob as roupas.

Enfim, a seleção do que se come se complexifica nas classes mais ricas. Não se come "qualquer coisa". Tampouco seus animais. Nenhuma pessoa de classe abastada daria ao seu cão o que se tornou conhecido como "ração de supermercado".

Falemos então de rações premium, petiscos, ovos de páscoa - já que pertencem à família -, rações à base de vegetais para tutores veganos de animais onívoros, padarias especializadas, com direito a degustação (ABONIZIO; BAPTISTELLA, 2017) e até mesmo vinho e cerveja, sem álcool obviamente, mas para que o animal de companhia, 
ao menos simbolicamente, possa estar na eucarística dos momentos festivos. Todos os cães terão acesso? Definitivamente não.

Figura 1 - Cerveja Dog Beer sem Álcool Sabor Carne para Cães.

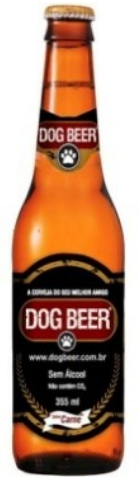

Fonte: https://www.petlove.com.br/cerveja-dog-beer-sem-alcoolsabor-carne-para-caes/p?sku=2319540

\section{A antropomorfização elitista e a animalização da pobreza}

Uma estudante de pós-graduação, atualmente já mestre, sob a minha orientação, enviou essa foto:

Figura 2 - Marmitas caseiras, para uma cadela, com divisão semanal das porções.

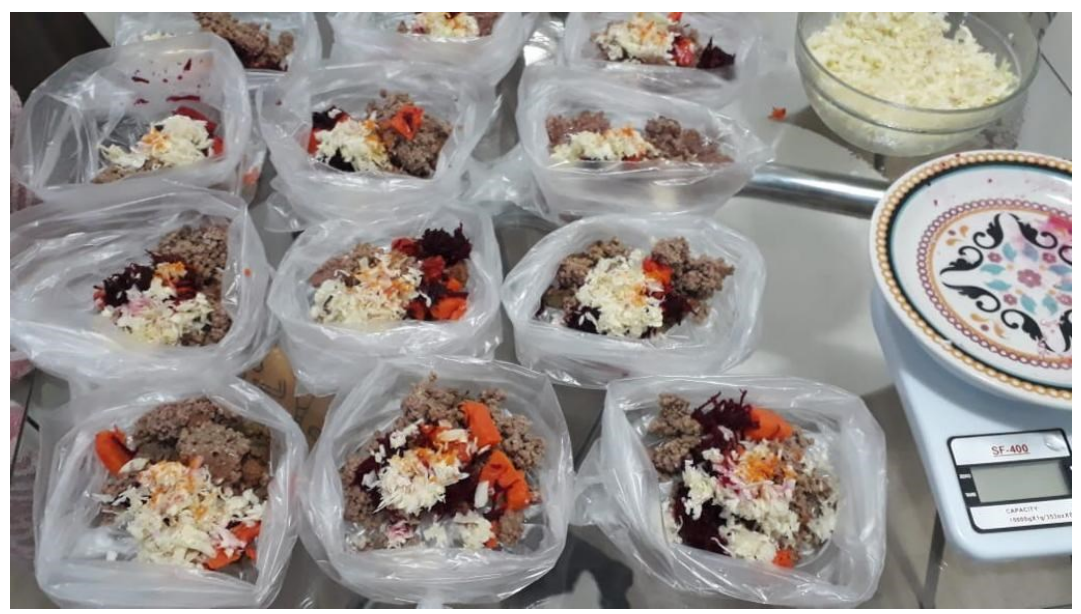

Fonte: foto de Fernanda Curtarelli. 
Trata-se da marmita feita por uma profissional em nutrição animal, caseira, sem nada industrializado, com os nutrientes necessários. Essa era a divisão semanal das porções para sua cadela. $O$ peso, calculado com exatidão, como vemos pela balança ao lado direito da foto.

Não carece de comprovação a crítica, falsa ou verdadeira, sobre o fato de que os alimentos industrializados ou ultraprocessados são nocivos aos organismos. Em se tratando de família, quem se arrisca? Hoje, a moda é o livro de receitas com ingredientes naturais ou as rações que divulgam utilizar partes nobres, naturais ou orgânicas. E isso é uma questão de classe. Exatamente o que significa? Que pessoas humanas ou não humanas podem ter peso superior do determinado - de modo questionável - nas tabelas e mesmo assim serem desnutridas? Podem ter gordura, sobrepeso, mas isso também pode significar anemia e desnutrição (OBESIDADE E DESNUTRIÇÃO..., 2018). No site Saúde Brasil, a médica nutróloga Ana Parada afirma:

A obesidade e a desnutrição são doenças nutricionais que podem ou não ser relacionadas a problemas alimentares. Antigamente a obesidade e a desnutrição eram enxergadas como consequências. Se a pessoa tinha câncer, por exemplo, era normal ela estar mais magra. Se a pessoa era obesa, o problema era somente o sedentarismo. Hoje, os dois são percebidos como doenças. (OBESIDADE E DESNUTRIÇÃO..., 2018, n.p.).

No entanto, apesar de ser praticamente consensual tratar-se de dois problemas de saúde pública, o presidente Bolsonaro, em 19 de julho de 2019 (BOLSONARO: 'FALAR..., 2019) declarou que não se passa fome no Brasil, pois não se veem pessoas esqueléticas, mesmo entre as mais pobres. Sim, decerto as pessoas esqueléticas estão nas passarelas de Milão, há de se supor. Após um tempo, o presidente volta atrás e diz que há pessoas que passam mal, mas não fome, e evita discussão maior, segundo o Correio Braziliense na mesma data (BOLSONARO VOLTA..., 2019b). De todo modo, fica subentendido que os corpos mais esguios se situam em posição superior em classe social.

Ainda visando combater a desnutrição, o prefeito de São Paulo, João Dória (CONSELHO..., 2017), propõe a distribuição às pessoas em situação de rua ou vulnerabilidade do que ficou conhecido como ração humana, nome sugestivo para alimento distribuído aos humanos, uma vez que as rações já não são mais a tendência entre os animais tutelados por pessoas ricas, como já abordei acima. Segundo o político, a tal ração, também chamada de farinata, tem os nutrientes necessários e é produzida a 
partir da desidratação de alimentos próximos à data de vencimento, o que prolongaria seu tempo de aptidão para o consumo, evitando o descarte. Várias instituições e profissionais da nutrição, através de seus representantes, se opuseram à proposta por tratar-se de um alimento ultraprocessado de qualidade duvidosa. Para complexificar a localização de pessoas humanas e não humanas na sociedade, o prefeito afirma que pobre tem fome e não hábito alimentar. Fala essa que poderia ser pensada ao referir-se a animais e quando estes eram considerados autômatos, como no discurso cartesiano, mas fica extremamente deslocada quando confrontada com a proliferação de alimentos para animais que decidem o que gostam ou não gostam.

Por exemplo, em uma pesquisa realizada acerca dos conflitos éticos entre tutores veganos e animais tutelados, eu e minha parceira encontramos os biscoitos artesanais de maçã, banana e aveia, totalmente artesanais e em "charmosas embalagens" produzidos pela marca VegPet, que agradaram a tutora e seus animais (ABONIZIO; BAPTISTELLA, 2016). Em um comentário dos consumidores extraído do site da marca (www.vegpet.com.br), pudemos ler quando realizamos a pesquisa:

"Experimentei e têm mesmo gosto de fruta (bem suave). Meus bichinhos adoraram, mas eles comem até pedras, se estiverem bem temperadinhas. Como por recomendação do homeopata, endocrinologista e clínico geral há anos eles não comem ração, apenas comida natural, essa parece uma sobremesa perfeita!"

Se considerarmos a divisão das refeições como parte da cultura, e nem todas as culturas têm o hábito da sobremesa - aliás, esse costume só chega ao Brasil com os portugueses, segundo Cascudo (2004) -, podemos deduzir que os "bichinhos" da pessoa que postou o comentário têm hábito alimentar. Fato negado aos pobres, que, conforme o já citado político, têm apenas fome. Mas até mesmo a existência da fome será negada por Bolsonaro que, em abril de 2017, diz que não acredita na fome e na desnutrição, uma vez que ironiza a corpulência de um morador de um quilombo, afirmando que a pessoa mais leve do lugar pesaria ao menos sete arrobas, não servindo nem mais para procriar. Não foi a única vez que Bolsonaro utilizou o índice de medida arroba para referir-se a negros, um índice utilizado principalmente para medição de peso de animais de corte. Ou seja, Bolsonaro animaliza quilombolas, negros e gordos, revelando um pacote complexo de preconceitos a borrar a fronteira entre animalidade e humanidade (FREIRE, 2020).

Das falas do presidente e da proposta do prefeito de São Paulo, concluímos que a fome é fictícia, pois a obesidade reina entre os corpos periféricos ou a desnutrição pode ser combatida com farelos de alimentos ultraprocessados chamados de ração, 
afinal, pobre não tem cultura alimentar. Uma vez mais, a cultura, traço que é tido amplamente, embora não consensualmente, se considerarmos estudos etológicos, como exclusivamente humano, é excluída desse exemplar, sobre o qual recai um discurso animalizante no sentido de inferiorização.

$\mathrm{O}$ alimento que cria o vínculo, desejado ou indesejado, também pode destruir vínculos e vidas. Assim, no bairro Jardim das Américas, em Cuiabá-MT, era comum distribuição de rações para gatos vadios, hábito voluntário e abnegado de pessoas com empatia aos animais em situação de rua, mas altamente criticado pelos moradores dos condomínios da região. Nesse mesmo bairro, no dia dos namorados de 2016, presenciei a morte de gatos que circulavam pela região por ingestão de carne envenenada.

Essa prática de assassinato não se restringe aos animais. Na Grande São Paulo, em Itapevi, a morte de moradores de rua por envenenamento ou contaminação por meio de marmitas doadas também tem sido investigada (MARMITAS..., 2020).

Assim, os problemas vistos como sociais - bichos e pessoas indesejadas tornam-se problemas sociológicos a serem investigados em sua dimensão de estratificação social, papel social dos alimentos que nutrem, garantem a vida ou causam a morte, intencionalmente, como no caso dos envenenamentos de animais humanos e não humanos, ou não intencionalmente, como no caso de herpes causado pela alimentação de símios por turistas em Bom Jardim, Mato Grosso ${ }^{1}$. Cabe ainda ressaltar que os humanos, no caso moradores de rua e outros sujeitos subalternos, podem não ter sua humanidade plenamente reconhecida, uma vez que, repito, a cultura lhes é negada, como deduzido das falas dos políticos Doria e Bolsonaro.

Uma vez mais, a ambiguidade entre o que é ou não humano, que é ou não digno de possuir ou tutelar não humanos, baseia-se em uma desigualdade não cientificamente criada, mas politicamente instaurada através de todo processo de colonialidade do qual ainda não nos libertamos, apesar do crescimento dos estudos decoloniais.

Os corpos e a comida tornam-se fatores de distinção social e interespecífica. Gordos e pobres podem situar-se, algumas vezes, como animais, monstros ou coisas. Assim, Kulick (2009) relata o caso de Lola, uma chihuahua posta em três programas diferentes de emagrecimento para cães, com exercícios, dietas, hidroginástica, ao custo de US\$ 1.400. Depois de dez semanas de tratamento, perdeu 450 g. Nem todos os humanos podem ter esse tratamento, e podem ter uma dieta e uma rotina de trabalho que dificulta, senão impossibilita, a boa nutrição - ainda que haja controvérsias sobre o que isso significa. O peso não pesa só na balança, vai para aparência, não dos animais que

\footnotetext{
${ }^{1}$ Informação dada por uma veterinária de Cuiabá acerca de outro estudo sobre turismo ecológico, que está sendo realizado dentro do projeto maior que engloba este artigo.
} 
não se julgam por esses olhos, mas dos humanos que se sentem feios, monstruosos ou desumanizados.

Mas, para acabar com a pobreza, o melhor não seria fornecer comida de qualidade, mas esterilizar os pobres para não procriarem (BRAGON, 2018), pois, segundo o então ainda presidenciável Bolsonaro, o afrodescendente de "no mínimo sete arrobas" não servia mais nem pra "procriador" como afirmou na visita à comunidade quilombola (FREIRE, 2020). Em primeiro lugar, o corpo da pessoa de quem se fala é motivo de juízo acerca de sua humanidade, uma vez que, como já disse antes, a arroba não é unidade de medida comum entre humanos. Visando acabar com a miséria, caos e violência, Bolsonaro defende a esterilização dos pobres, apesar de a lei no 9263/1996 (BRASIL, 1996) proibir qualquer ação coercitiva de controle demográfico ou indução à esterilização.

Mais uma vez a aproximação entre pobreza e animalidade é vista. Há a campanha para esterilização dos animais indesejados de rua, que também não servem para procriadores porque não têm pedigree. E os animais que portam a genealogia, sobretudo a da moda, sofrem horrores já denunciados em vários lugares, especialmente as fêmeas, que são exploradas apenas como fábrica de filhotes a serem vendidos.

Bolsonaro não vê a educação como um objetivo para minimizar a situação de desigualdade social, pois, em sua opinião, quem não tem condições de ter filhos simplesmente não deveria tê-los. Tal discurso também é visto acerca dos animais a serem adotados. Nos sites de adoção, há que se provar que o interessado tem condições de ter um cão ou gato, pois isso implica gastos com vacinas, rações, de preferência premium, visitas regulares a veterinários, tempo para que os animais gozem de companhia, carinho, segurança e boa saúde. O cumprimento de uma série de regras para a adoção é exigido do candidato a querer gozar da companhia de animal, como estudou Osorio (2011) em redes de proteção a gatos de rua. Pode não ser intencional, mas as regras de adoção criam uma apartação entre quem pode ou não pode gozar da companhia de um animal de estimação e essa apartação está ligada, de maneira intrínseca, às condições financeiras. Levando ao extremo, poderíamos afirmar que pobres não deveriam ter filhos, nem humanos nem não humanos, em se tratando de família multiespécie. A eles são negados esses direitos.

Com política de alimentação restrita, seja por dieta forçada, constrangimento financeiro, cultura alimentar: animais e pessoas pobres (não apenas em situação de rua) tendem à obesidade que falseia o problema da fome, do direito à segurança alimentar, da alimentação justa, limpa e de qualidade a todos.

Para reduzir o problema, como essas populações são vistas, a política atual não pensa na possibilidade de inclusão dos excluídos, mas faz campanha para excluí-los 
ainda mais, inclusive de sua possibilidade de existência: esterilização compulsória dos pobres. Uma imitação da política para controle dos animais de rua considerada mais eficiente que a carrocinha.

Os animais ricos, e dos ricos, tendem a ser humanizados, com dietas feitas por profissionais da nutrição animal, preparadas artesanalmente e com direito a atividade física, acompanhamento médico, odontológico e psicológico. Não à toa, os caninos mais comprados são as fêmeas com pedigree, pela probabilidade de retorno financeiro com a venda de filhotes. Já aos humanos pobres, aplica-se, ou pretende-se aplicar, as políticas de controle por meio de esterilização de mulheres, visando diminuir ou eliminar pragas, como se faz aos demais animais que (sobre)vivem na cidade de modo indesejado. Num e noutro caso, a fronteira entre humano e animal se confunde, mas há uma diferença, e marcante: no primeiro caso, o tratamento dos animais se aproxima do estilo de vida humano; no segundo caso, os humanos passam a ser tratados como os animais vistos como pragas. Um nivela por cima, o outro, por baixo.

\section{AnIMALS, FOOD, SOCIAL STRATIFICATION}

ABSTRACT: Humanity and animality are concepts constructed in order to create a certain understanding of what it is to be human. Although man is an animal, however, he is the only animal who cooks and does not do it only for his species. Humans feed on animals and feed other animals, whether for breeding, maintenance and selling, or for animals chosen for companionship. In this work, I propose a reflection based on food and body shape, these factors being determinant, although subject to social mobility, of the position occupied by human and non-human animals in the class structure.

KEYWORDS: Human-animal relations. Food. Social stratification.

\section{Animales, alimentos y Clase social}

RESUMEN: Humanidad y animalidad son conceptos construidos para crear una cierta comprensión de lo que es ser humano. Aunque el hombre es un animal, no obstante, es el único animal que cocina y no lo hace solo para su especie. Los seres humanos se alimentan de animales y alimentan a otros animales, ya se trate de ganado, engorde y venta, o los animales de compañía. En este trabajo, propongo una reflexión a partir de la alimentación y la forma corporal, siendo estos factores determinantes, aunque 
sujetos a la movilidad social, de la posición que ocupan los animales humanos y no humanos en la estructura de clases.

PALABRAS CLAVE: Relaciones humano-animal. Alimentación. Estratificación social.

\section{REFERÊNCIAS}

ABONIZIO, J.; BAPTISTELLA, E. Pets e petiscos: o consumo alimentar como mediador do afeto entre tutores e animais de estimação. Monumento Documento, v. 21, n. 1, p.212-224, 2017.

ABONIZIO, J.; BAPTISTELLA, E. À mesa com cães e gatos: ração vegetal e fronteiras interespécies. Iluminuras, Porto Alegre, v. 17, n. 42, p.107-135, ago./dez. 2016.

ABONIZIO, J.; JIMENEZ-JIMENEZ, M. L. Isso sim é comida de madame: um estudo sobre a relação entre práticas alimentares e mobilidade social ascendente. Repocs, São Luís, v. 15, n. 29, p.209-232, jan./jul. 2018.

AMON, D.; MENASCHE, R. Comida como narrativa da memória social. Sociedade e Cultura, Goiânia, v. 11, n. 1, p.13-21, jan./jun. 2008.

APPADURAI, A. (org.). A vida social das coisas: as mercadorias sob uma perspectiva cultural. Niterói: Editora da Universidade Federal Fluminense, 2008.

ARLUKE, A.; SANDERS, C. Regarding animals. Philadelphia: Temple University Press, 1996.

BAPTISTELLA, E.; ABONIZIO, J. O cachorro santo e as éticas de proteção animal: uma reflexão a partir da semiótica da cultura. In: POSSARI, L. H. V. (org.). Semioses: do cotidiano à cibercultura. Cuiabá: EdUFMT, 2014. p.85-100.

BAPTISTELLA, E.; ABONIZIO, J. Entre espécies e ciências: uma reflexão sobre a utilização de argumentos científicos para legitimação da causa animal. INTERthesis, Florianópolis, v. 13, n. 2, p.76-105, maio/ago. 2016.

BAPTISTELLA, E.; ABONIZIO, J. Os gatos do tribunal de justiça e as fronteiras entre homens e animais. ECOS: Estudos Contemporâneos da Subjetividade, Campos dos Goytacazes, v. 5, n. 2, p.188-199, 2015.

BERGER, P.; LUCKMANN, T. A construção social da realidade: tratado de sociologia do conhecimento. Petrópolis: Vozes, 1999. 
BOLSONARO: 'FALAR que se passa fome no Brasil é uma grande mentira'. Veja, 19 jul. 2019. Disponível em: https:/veja.abril.com.br/politica/bolsonaro-falar-que-se-passa-fome-nobrasil-e-uma-grande-mentira/. Acesso em: 16 ago. 2020.

BOLSONARO VOLTA atrás em declaração sobre não existir fome no Brasil. Correio Braziliense, 19 jul. 2019. Disponível em https:/www.correiobraziliense.com.br/app/noticia/politica/2019/07/19/interna_politica,772301 /bolsonaro-volta-atras-em-declaracao-sobre-nao-existir-fome-no-brasil.shtml. Acesso em: 15 ago. 2020.

BRAGON, R. Bolsonaro defendeu esterilização de pobres para combater miséria e crime. Folha de S. Paulo, 11 jun. 2018. Disponível em: https:/www1.folha.uol.com.br/poder/2018/06/bolsonaro-defendeu-esterilizacao-de-pobrespara-combater-miseria-e-crime.shtml. Acesso em: 31 jul. 2020.

BRASIL. Lei $\mathbf{n}^{\mathbf{0}}$ 9.263, de 12 de janeiro de 1996. Regula o $\S 7^{\circ}$ do art. 226 da Constituição Federal, que trata do planejamento familiar, estabelece penalidades e dá outras providências. Brasília, 1996. Disponível em: http://www.planalto.gov.br/ccivil_03/leis/19263.htm. Acesso em: 15 ago. 2019.

CASCUDO, L. C. História da alimentação no Brasil. São Paulo: Global, 2004.

CHUAHY, R. Manifesto pelos direitos dos animais. São Paulo: Record, 2009.

CLASTRES, P. A sociedade contra o Estado. Rio de Janeiro: Francisco Alves, 1978.

CONSELHO de Segurança Alimentar é contra ração humana de Doria. Justificando, 19 out. 2017. Disponível em: http://www.justificando.com/2017/10/19/conselho-de-segurancaalimentar-e-contra-racao-humana-de-doria/. Acesso em: 31 jul. 2020.

DE WAAL, F. Moral behavior in animals. TEDxPeachtree, nov. 2011. Disponível em: https://www.ted.com/talks/frans_de_waal_moral_behavior_in_animals. Acesso em: 15 ago. 2020 .

DOUGLAS, M.; ISHERWOOD, B. O mundo dos bens: para uma antropologia do consumo. Rio de Janeiro: Editora UFRJ, 2009.

FISCHLER, C. EI (h)ominívoro: el gusto, la cocina y el cuerpo. Barcelona: Anagrama, 1995.

FREIRE, S. Bolsonaro diz que eleitor tem 'oito arrobas' e deputado 'deu uma queimadinha' ao nascer. Alma Preta, 2 mar. 2020. Disponível em:

https://almapreta.com/editorias/realidade/bolsonaro-diz-que-eleitor-tem-oito-arrobas-edeputado-deu-uma-queimadinha-ao-nascer. Acesso em: 18 ago. 2020.

GIL, J. Monstros. Lisboa: Quetzal, 1994. 
GOFFMAN, E. Estigma: notas sobre a manipulação da identidade deteriorada. Rio de Janeiro: LTC, 1975.

GOLDENBERG, M. Cultura e gastro-anomia: psicopatologia da alimentação cotidiana. Entrevista com Claude Fischler. Horizontes Antropológicos, Porto Alegre, ano 17, n. 36, p.235-256, 2011.

INGOLD, T. Humanidade e animalidade. Revista Brasileira de Ciências Sociais, São Paulo, ano 10, n. 28, 1995. Disponível em:

http://www.anpocs.com/images/stories/RBCS/28/rbcs28_05.pdf. Acesso em: 18 ago. 2020.

KULICK, D. Animais gordos e a dissolução da fronteira entre as espécies. Mana, Rio de Janeiro, v. 15, n. 2, p.481-508, 2009.

MAFFESOLI, M. No fundo das aparências. Petrópolis: Vozes, 1999.

MAGALHÃES-SANT’ANA, M. Consciência animal: para além dos vertebrados. Jornal de Ciências Cognitivas, p.1-13, mar. 2009.

MARMITAS envenenadas podem ter provocado a morte de moradores de rua em São Paulo. NH, 23 jul. 2020. Disponível em:

https:/www.jornalnh.com.br/noticias/pais/2020/07/23/marmitas-envenenadas-podem-terprovocado-a-morte-de-moradores-de-rua-em-sao-paulo.html. Acesso em: 15 ago. 2020.

MARTON, F. Chimpanzés entendem de cozinha. Superinteressante, 31 out. 2016. Disponível em: https://super.abril.com.br/ciencia/chimpanzes-entendem-de-cozinha. Acesso em: 18 ago. 2020 .

NACONECY, C. M. Ética animal... ou uma "ética para vertebrados"?: um animalista também pratica especismo? Revista Brasileira de Direito Animal, v. 2, n. 3, Salvador, p.19-153, 2007.

OBESIDADE E DESNUTRIÇÃO: nem tudo é o que parece. Saúde Brasil, 26 fev. 2018. Disponível em: https://saudebrasil.saude.gov.br/ter-peso-saudavel/obesidade-e-desnutricaonem-tudo-e-o-que-parece. Acesso em: 18 ago. 2020.

OBESIDADE, SAIBA tudo sobre essa epidemia! Neobaros, 2020. Disponível em: https://bariatricaemetabolicabh.com.br/obesidade-epidemia-mundial/. Acesso em: 15 ago. 2020 .

OSORIO, A. Posse responsável: moral, ciência e educação ambiental em um grupo de protetores de gatos de rua. Revista de Antropologia Social dos Alunos do PPGAS-UFSCar, São Carlos, v. 3, n. 2, p.51-75, jul./dez. 2011.

PAIS, J. M. Lufa-lufa quotidiana: ensaios sobre cidade, cultura e vida urbana. Lisboa, Imprensa de Ciências Sociais, 2010. 
POULAIN, J.-P. Sociologia da obesidade. São Paulo: Senac, 2013.

RAMBO, L.; RENK, A. A. A relação homem/natureza-animais: uma revisão da literatura sobre o descaminho da cultura ocidental. Revista de Ciências Ambientais, Canoas, v. 2, n. 2, p.61 $78,2008$.

RING, K.; WALLSTON, K.; COREY, M. Mode of debriefing as a factor affecting subjective reaction to a Milgram-type obedience experiment: an ethical inquiry. Representative Research in Social Psychology, Chapel Hill, v. 1, n. 1, p.67-88, 1970.

RITTO, C.; ALVARENGA, B. A casa agora é deles. Veja, São Paulo, n. 2429, p.71, 2015.

RODRIGUES, J. C. Tabu do corpo. Rio de Janeiro: Achiamé, 1983.

SEGATA, J. Quando o animal dura mais que a estimação. Mana, Rio de Janeiro, v. 22, n. 3, p.831-856, 2016.

VIGARELLO, G. As metamorfoses do gordo. Petrópolis: Vozes, 2012.

Recebido em 20/08/2020.

Aprovado em 02/09/2020. 